\title{
Empirical Examination of Intersectoral Linkages Between Tourism and Regional Economy by Using the Social Accounting Matrix
}

\begin{abstract}
Submitted 21/12/19, $1^{\text {st }}$ revision 13/01/20, $2^{\text {nd }}$ revision 20/02/20 accepted 10/03/30
\author{
I Made Adnyana ${ }^{1}$, Hasanudin ${ }^{2}$, Andini Nurwulandari ${ }^{3}$
}

Abstract:

Purpose: The main objectives of this study are to analyze the role of the tourism sector as measured by multiplier effects and linkages in the economy's output, employment, and income distribution.

Design/methodology/approach: The Social Accounting Matrix model was utilized by using the methods of Linkage Analysis, Multiplier Analysis, Multiplier Decomposition, Structural Path Analysis (SPA) and simulation analysis.

Findings: The results show that the tourism sector contributes greater portion to the economic output, than other economic sectors in Bali. It also generates more equal income distribution and employment. However, the simulation shows that the tourism sector has not focused on increasing the income of the lower classes in rural areas.

Practical implications: This study is practically useful for policy makers and entrepreneurs in the tourism sector to expand the tourism base in rural areas by actively involving lower economic groups as labor and supplier partners.

Originality/value: This study originally investigated the linkages between agriculture and tourism from various economic perspectives of output, income distribution and employment.
\end{abstract}

Keywords: Tourism, agriculture, social accounting matrix, Linkage Analysis, Multiplier Analysis.

JEL code: G34.

Paper type: Research article.

\footnotetext{
${ }^{1}$ Universitas Nasional, Jl.Sawo Manila, Pejaten Barat, Pasar Minggu, Indonesia, email: hasanudin.unasjkt@yahoo.com

${ }^{2}$ Universitas Nasional, Jl.Sawo Manila, Pejaten Barat, Pasar Minggu,, Indonesia, email: imadeandyana.unas@yahoo.com

${ }^{3}$ Universitas Nasional, Jl.Sawo Manila, Pejaten Barat, Pasar Minggu, Indonesia, email: info@yourdoamin.com
} 


\section{Introduction}

The economic development of Bali Province is dominated by the tourism sector, besides the agricultural sector as another economic forerunner (Sutawa, 2012). It contributes to the development of regional economic output, employment and income (Table 1). Tourism in the economy can be included in all economic activities, classified into transportation sector, accommodation sector, intermediary sector, tourism attraction (Stabler et al., 2010). Other sectors related to tourism such as the food, beverage and textile industry, manufacture, restaurant, hotel, the travel and the cultural attractions are referred to as the tourism sector. Hence, this study aims to analyze the role of the tourism sector that is measured based on backward and forward linkages by analyzing the impact of the multiplier of the tourism sector, and the impact of the increase in final demand on output, labor and income distribution.

Table 1. Agriculture and Tourism Contributions to GRDP (2008-2011).

\begin{tabular}{|l|l|l|l|l|l|l|}
\hline Annual contribution & GRDP (\%) & Employment (\%) \\
\hline & Agriculture & Tourism & Other & Agriculture & Tourism & Other \\
\hline 2008 & $20 \%$ & $32 \%$ & $48 \%$ & $36 \%$ & $24 \%$ & $40 \%$ \\
\hline 2009 & $20 \%$ & $32 \%$ & $48 \%$ & $34 \%$ & $24 \%$ & $42 \%$ \\
\hline 2010 & $19 \%$ & $33 \%$ & $48 \%$ & $31 \%$ & $26 \%$ & $43 \%$ \\
\hline 2011 & - & - & - & $25 \%$ & $27 \%$ & $48 \%$ \\
\hline
\end{tabular}

The study is to analyze the role of tourism sectors as measured by multiplier effects of the sectors on the economy by investigating the tourism sector linkages in the economy, the impacts of the increase of the final demand on the economy's output, employment, and income distribution using the Social Accounting Matrix approach. In this study, the Social Accounting Matrix model was utilized by using the methods of Linkage Analysis, Multiplier Analysis, Multiplier Decomposition, Structural Path Analysis (SPA) and simulation analysis. It provides recommendations to the provincial government of Bali to carry out its economic development through the agricultural sector and tourism sector, based on role analysis and intersectoral linkages.

\section{Theoretical Review}

In Perroux's (1955) framework, key industries in an area are drivers for growth. Key industries play a dynamic role because of their ability to innovate. In addition, this kind of industry can form a separate cluster into an industry group that supports the main industries (Nurwulandari et al., 2019; Ugurlu et al., 2014; Thalassinos and Pociovalisteanu, 2009). The main industries are those who have strong forward relations. In addition to the main industries, Perroux (1955) uses the term driving industry (Adisasmita, 2008). In this context, there will be interdependencies between sectors. This dependence can be formulated in three types of interrelated effects: one, the effect of inter-industry linkages, measuring the effect of an increase in one unit of final demand at the level of production in each sector; second, the effect of interemployment interrelated effects, measuring the total employment in one sector as a 
result of changes in one final demand unit; and third, the linkage effect of income generation, measuring the effect of changes in one of the exogenous variables in the final demand for increased income (Chenery and Clark, 1959; Ginting, 2006; Thalassinos and Kiriazidis, 2003).

Among the various types of industries, the tourism economy is a sector that has strong inter-sectoral links and can be a key to regional and national growth, and can form another buffer industry group. The tourism economy is the part of the economy created by transactions made between tourists, related to spending on tourism, and the economic sector that provides goods and services. The Australian Bureau of Statistics (1994) divides the tourism economy into three elements: one, tourists, as consumers who consume goods and services while traveling; second, transactions to obtain goods and services both in travel and in tourist destinations; and third, economic units that provide goods and services to fulfill tourism activities.

To examine the inter-sectoral linkages, empirical examination is made by the Social Accounting Matrix (SAM). The SAM model can include several macroeconomic variables, such as taxes, subsidies, capital investigation. The Social Accounting Matrix model can fully describe all macroeconomic, sectoral, and institutional transactions in a balance sheet (Thorbecke, 1985). As it included in this system, home industry is the main focus of attention describing the ongoing distribution of household welfare according to household economic, social, geographical and demographic characteristics. Meanwhile, the production sector describes the business sectors producing goods and services that are sources of income (Daryanto and Hafizrianda, 2010).

Empirical investigation by using SAM approaches in tourism industry showed that the tourism sector has the potential to create GDP and employment, but is less able to make more income distributions, especially in agricultural sector and rural areas (Heriawan, 2004). Furthermore, particularly in Bali, through the expenditures of the central and regional governments, various physical and economic facilities were built including tourism facilities to anticipate an increase in tourist arrivals. An increase in tourist visits increases tourist spending, eventually increasing the multiplier effect and obtaining foreign exchange. Empirical investigation by using SAM in environmental aspects of tourism showed that tourism also creates negative externalities besides positive impacts (Antara, 1999). Bali's economy is mainly supported by the agricultural and the tourism sectors. All sectors need factors of production such as labor and capital. Factors of production obtain income that can be allocated through income between institutions of household institutions such as salaries, wages, and rental income, corporate institutions such as company profits, and government such as tax revenues. Hence, the Social Accounting Matrix model can be used to analyze the output produced by the production sectors, the amount of labor absorbed by each sector and the distribution of income from each production sector to the household group. 


\section{Research Methodology}

Linkage analysis is used to determine the magnitude of the level of the relationship of a sector to other sectors. The linkage analysis in this study is based on the Rasmussen's dual criteria (Daryanto and Hafizrianda, 2010). These criteria include measuring the index based on, first, sensitivity of dispersion and power dispersion, and secondly, the forward spread effect index and the backward spread effect index. Furthermore, the multiplier analysis used in this study is a multiplier with an average approach. The multiplier analysis that is the focus of this study includes the types of multiplier of gross output/production multiplier, employment multiplier and household multiplier (Daryanto and Hafizrianda, 2010). Lastly, simulation analysis is intended to find out how the impact of economic stimulus from the tourism sector, the magnitude of the stimulus of each sector, is when the agricultural sector is Rp. 100 billion, while the tourism sector 0 . Also when the tourism sector is Rp.100 billion while the agricultural sector is 0 , and the agricultural sector is Rp. 50 billion and the tourism sector is also Rp. 50 billion, based on the establishment of fixed capital of the Bali provincial budget in 2007 (BPS Bali, 2007)

\section{Results}

The analysis of intersectoral linkages showed that the backward linkage index which has a value of $1.83>1$ is the agriculture sector of the livestock sub-sector. This shows that an increase in one unit of output in the livestock sub-sector is more likely to increase upstream sector output by 1.83 units. Then, in the tourism sector, the textile industry sub-sector scored 1.78. This means that an increase in one unit of output is more likely to increase the upstream sector by 1.78 units. Meanwhile, the agricultural sector and other tourism sectors have a backward linkage of less than one which means that these sectors do not have a large upstream effect. Future Linkage Index Analysis shows that the Livestock sub-sector has a value of 2.11. This shows that an increase in one unit of output is more likely to increase the output of the downstream sector by 2.11 units. In the tourism sector, the food industry sub-sector has a value of 1.21. This means that an increase in one unit of output is more likely to increase the output of the downstream sector by 1.21 units (Table 2). The multiple impact analysis shows that in the agriculture sector, the fisheries sub-sector has an index 0.8044 , followed by livestock 0.7146 , and forestry 0.7125 . For the tourism sector, the textile industry has an index 0.8093 , followed by the handicraft industry 0.7971 and cultural attractions 0.7951 .

Table 2. Intersectoral Linkages by subsector (percentage)

\begin{tabular}{|l|l|l|}
\hline Subsector & Backward & Forward \\
\hline Agriculture Sector & & \\
\hline Animal husbandry & 1.83 & 2.11 \\
\hline Agriculture & 0.92 & 0.94 \\
\hline Plantation & 0.88 & 0.85 \\
\hline Tourism Sector & & \\
\hline Restaurants & 0.79 & 0.95 \\
\hline
\end{tabular}




\begin{tabular}{|l|l|l|}
\hline Hotel & 0.77 & 0.76 \\
\hline Travel Agency & 0.78 & 0.80 \\
\hline
\end{tabular}

Table 3. Multiplier Impact by subsector (percentage)

\begin{tabular}{|l|l|}
\hline Subsector & Index \\
\hline Agriculture Sector & \\
\hline Fishery & 0.8044 \\
\hline Husbandry & 0.7146 \\
\hline Forestry & 0.7125 \\
\hline Tourism Sector & \\
\hline Textile \& Apparel & 0.8093 \\
\hline Handicrafts & 0.7971 \\
\hline Cultural Attractions & 0.7951 \\
\hline
\end{tabular}

The simulation analysis conducted with the calculation of the final value added to output, labor and household income. The impact of an increase in final demand on output showed that simulation 2 produces the highest output (315,26 million IDR) compared to simulations 1 and 3, amounting to 290,30 million IDR and 302,69 million IDR, respectively. For the simulation of the effect of increasing the final demand for labor, simulation 1 can absorb more labor (70.506 workers) compared to simulations 2 and 3, 51.114 and 60.810 workers, respectively. For the impact of an increase in final demand on household income, simulation 2 yields a higher home income of IDR 19,71 million, compared to simulations 1 and 2, 17,92 and 18,823 (Table 4).

Table 4. Final Value Added to Output, Labor and Household Income

\begin{tabular}{|l|l|l|l|}
\hline Information & Simulation1 & Simulation2 & Simulation3 \\
\hline Output (million IDR) & 290,073 & $\mathbf{3 1 5 , 2 6 4}$ & 302,669 \\
\hline Labor (people) & $\mathbf{7 0 , 5 0 6}$ & 51,114 & 60,810 \\
\hline Household Income (million IDR) & 17,929 & $\mathbf{1 9 , 7 1 7}$ & 18,823 \\
\hline
\end{tabular}

Moreover, the income inequality of household groups found from SAM 2007, as shown in Table 5, is the lowest in farm workers, while agricultural entrepreneurs are 19 times higher than that of farm workers, (lower in the villages, 18 times more). In this case the most ideal, simulation 2 , showed that the upper class in the urban areas decreased the proportion of income from 41.37 to 37.34 , the lowest compared to simulation 1 and 3.

Table 5. Household income equality by employment (percentage)

\begin{tabular}{|l|l|l|l|l|l|}
\hline Household Group & R/U & SAM & Sim. 1 & Sim. 2 & Sim. 3 \\
\hline Farm workers & Rural & 1.00 & 1.00 & 1.00 & 1.00 \\
\hline Agricultural entrepreneurs & Rura; & 19.21 & 23.44 & 19.11 & 21.16 \\
\hline Other groups & Rural & 18.63 & 18.43 & 17.86 & 18.13 \\
\hline Income Recipients & Rural & 4.46 & 4.61 & 4.30 & 4.45 \\
\hline Upper group & Rural & 21.89 & 22.92 & 20.00 & 21.38 \\
\hline Lower group & Urban & 28.94 & 22.99 & 27.27 & 25.24 \\
\hline Income Recipients & Urban & 7.21 & 6.63 & 6.97 & 6.95 \\
\hline Upper Group & Urban & 41.37 & 37.87 & 37.34 & 37.59 \\
\hline
\end{tabular}


The results reveal that the tourism sector has the highest role, compared to other sectors. The top priority subsector in the tourism sector is the textile industry. This sub-sector is able to attract the upstream sector and is also able to push the downstream sector. The tourism sector that received the highest income was the the textile industry, followed by the handicraft industry and the cultural attractions.

Impact analysis shows that the tourism sector produces the highest output for an increase in final demand for output. For the impact of increasing final demand for employment, the tourism sector is smaller in absorbing labor compared to other sectors. For the impact of increasing final demand on household income, the tourism sector has the highest impact on household income. In addition, household income inequality in the tourism sector has the lowest inequality. This shows that tourism provides the highest increase in final demand for output, household income and has the lowest inequality. To increase employment in the tourism sector, the creation of labor-intensive employment opportunities by providing employment policies that are pro and pro-poor can be emphasized to expand the effects of tourism in the poor. This is in accordance with the arguments from various literature to increase the effect of tourism for the lower group (pro poor tourism) (Ashley and Roe, 2001; Harrison, 2008; Chok et al., 2007; Rogerson, 2006; Torres and Momsen, 2004).

\section{Conclusion}

The results reveal that the tourism sector has the highest role, compared to other sectors in economic output, employment and income distribution. The top priority subsector in the tourism sector is the textile industry. This sub-sector is able to attract the upstream sector and is also able to push the downstream sector. The tourism sector that received the highest income was the the textile industry, followed by the handicraft industry and the cultural attractions. The simulation results show that increased investment in potential sectors shows the important role of the tourism sector in improving the economy of the province of Bali.

These contributions include increased output and employment. However, the results show that there is an imbalance in the distribution of household income among rural labor groups. This practically implies that the development of a future economic strategy in Bali is not, especially in the tourism sector, aimed not only at increasing output and labor, but also on income distribution among household groups, especially in rural areas. The development of the tourism sector which has a direct impact on increasing the income of low-income households, needs to be prioritized such as the restaurant sub-sector, the hotel sub-sector and the travel agency sub-sector. In addition, rationalizing regulatory and incentive structures is also needed to increase the effect of tourists on income distribution, in addition to placing agro-industry as a priority in pursuing industrialization.

\section{References:}


Adisasmita, R. 2008. Regional Development, Concepts and Theories. Yogyakarta, Graha Ilmu.

Antara, M. 1999. The Impact of Government and Tourist Spending on Bali Economic Performance: Social Accounting Matrix Approach. Doctoral Desertation, Bogor Agricultural University.

Ashley, C., Roe, D. 2001. Pro-poor tourism strategies: Making tourism work for the poor: A review of experience. Deloitte and Touche, IIED and the ODI.

Australian Bureau of Statistics. 1994. Framework for the Collection and Publication of Tourism Statistics. Australian Bureau of Statistics. Canberra.

Chenery, H.B., Clark, P.G. 1959. Interindustry Economics. New York, John Wiley \& Sons.

Chok, S., Macbeth, J., Warren, C. 2007. Tourism as a tool for poverty alleviation: A critical analysis of 'pro-poor tourism' and implications for sustainability. Current issues in Tourism, 10(2-3), 144-165.

Daryanto, A., Hafizrianda, Y. 2010. Analysis of Input-Output and Social Accounting Matrix, for Regional Economic Development. Bogor, IPB Press.

Ginting, R. 2006. Impact of Government Spending on Growth and Distribution of Revenues in North Sumatra: Approach to the Socio-Economic Balance System. Doctoral Dissertation, Postgraduate School, Bogor Institute of Agriculture, Bogor.

Harrison, D. 2008. Pro-poor tourism: A critique. Third world quarterly, 29(5), 851-868.

Heriawan, R. 2004. The Role and Impact of Tourism on the Indonesian Economy: A Model I - O and Social Accounting Matrix Approach. Doctoral Dissertation at Bogor Agricultural University.

Perroux, F. 1955. Note sur la notion de pole de croisssance. economie appliquée. Economie Appliquee, (8).

Rogerson, C.M. 2006. Pro-poor local economic development in South Africa: The role of pro-poor tourism. Local environment, 11(1), 37-60.

Stabler, J., Papatheodorou, A., Sinclair, M. 2010. The Economics of Tourism, Second Edition. New York, Routledge.

Sutawa, G.K. 2012. Issues on Bali tourism development and community empowerment to support sustainable tourism development. Procedia economics and finance, 4(1), 413-422.

Nurwulandari, A., Adnyana, I.M., Hasanudin. 2019. Did inter-regional trade agreements bring mutual benefits? An empirical scheme of Indonesian commodity exports in Asean-China Free Trade Area. International Journal of Financial Research, 10(6), 241-249.

Thalassinos, I.E. and Kiriazidis, T. 2003. Degrees of Integration in International Portfolio Diversification: Effective Systemic Risk. European Research Studies Journal, 6(12), 119-130.

Thalassinos, I.E. and Pociovalisteanu, M.D. 2009. The Structural Funds and the Economic and Social Cohesion Process. Annals-Economy Series 1, 313-330.

Thorbecke, E. 1985. The Social Accounting Matrix and Consistency Type Planning Model. In A World Bank, Symposium Social Accounting Matrix Model (Edited by Pyaat, G. and J.I. Round). The World Bank, Washington, DC, USA, 207- 256.

Torres, R., Momsen, J.H. 2004. Challenges and potential for linking tourism and agriculture to achieve pro-poor tourism objectives. Progress in Development Studies, 4(4), 294-318.

Ugurlu, E., Thalassinos, E., Muratoglu, Y. 2014. Modeling Volatility in the Stock Markets using GARCH Models: European Emerging Economies and Turkey. International Journal of Economics and Business Administration, 2(3), 72-87. 